\title{
The Structure and Stability of Uranyl Arsenate Minerals: Zeunerite and Metazeunerite
}

\author{
FIONA MACIVER-JONES, CAROLINE KIRK
}

Dept. of Chemistry, University of Edinburgh, Edinburgh, UK (fmacive2@ed.ac.uk)

Uranium and arsenic are common co-contaminants in uranium mine tailings. Both $\mathrm{U}(\mathrm{VI})$ and $\mathrm{As}(\mathrm{V})$ pose a significant threat to public health as these species are highly soluble, toxic and carcinogenic. However, precipitation of the secondary uranyl-arsenate minerals, zeunerite and metazeunerite $\left(\mathrm{Cu}\left(\mathrm{UO}_{2}\right)_{2}\left(\mathrm{AsO}_{4}\right)_{2} \cdot n \mathrm{H}_{2} \mathrm{O}, \quad n=12\right.$ and 8, respectively), has been found to significantly reduce dissolved concentrations of $\mathrm{U}(\mathrm{VI})$ and $\mathrm{As}(\mathrm{V})$ across numerous contaminated sites [1-2]. Formation of these mineral phases provides a natural sink and prevents migration of $\mathrm{U}(\mathrm{VI})$ and $\mathrm{As}(\mathrm{V})$ in the environment. Understanding the structure and stability of (meta)zeunerite is therefore highly important in terms of contaminant attenuation and the development of remediation strategies.

We have investigated the structures of zeunerite and metazeunerite using a combination of synchrotron powder $\mathrm{X}$ ray diffraction, single crystal $\mathrm{X}$-ray diffraction, neutron powder diffraction, infrared spectroscopy, and computational methods. Dominant X-ray scattering exhibited by uranium and arsenic has meant that previous studies have been unable to experimentally locate the position of hydrogen atoms within the crystal lattice using X-ray techniques alone [3, 4]. As presented here, our results suggest that zeunerite and metazeunerite have a higher degree of structural disorder relative to their phosphate analogues, torbernite and metatorbernite $\left(\mathrm{Cu}\left(\mathrm{UO}_{2}\right)_{2}\left(\mathrm{PO}_{4}\right)_{2} \cdot n \mathrm{H}_{2} \mathrm{O}, \quad n=12\right.$ and 8, respectively). We believe that the greater structural disorder contributes to the lower stability of arsenate phases. Leaching experiments using a variety of solutions $(\mathrm{pH} 1-13)$ have shown that mineral degradation increases as a function of increasing As content $\left(\mathrm{Cu}\left(\mathrm{UO}_{2}\right)_{2}\left(\mathrm{PO}_{4}\right)_{2-x}\left(\mathrm{AsO}_{4}\right)_{x} \cdot n \mathrm{H}_{2} \mathrm{O}, x=0\right.$ 2 ), particularly with respect to U-leaching. These findings could have significant implications for the remobilization of carcinogenic contaminants, and suggest that partial incorporation of phosphate into the (meta)zeunerite structure may lead to a more viable long-term sink of $\mathrm{U}(\mathrm{VI})$ and As $(\mathrm{V})$.

[1] Corkhill et al. (2017) Materials Degeneration 1, 1-7

[2] Zhou et al. (2019) Chem. Eng. Journal 358, 393-401

[3] Hennig et al. (2003) Z. Kristallogr. 218, 37-45.

[4] Locock and Burns (2003) Can. Min. 41, 489-502 